\title{
Indian Mustard and Allyl Isothiocyanate Inhibit Sclerotium rolfsii
}

\author{
Stephanie G. Harvey, Heather N. Hannahan, and Carl E. Sams ${ }^{1}$ \\ Department of Plant and Soil Sciences, University of Tennessee, Knoxville, TN 37901
}

\begin{abstract}
AdDITIONAL INDEX wORDs. Brassica, southern blight, soilborne pathogen, biofumigation
Abstract. Allyl isothiocyanate (AITC) is the predominant isothiocyanate produced by damaged tissues of Indian mustard (Brassica juncea (L) Czerniak). This study investigated Indian mustard and AITC mediated suppression of mycelial growth and sclerotial germination of Sclerotium rolfsii Saccardo, a common soilborne pathogen. Indian mustard (IM) treatments of $0,0.1,0.2,0.6,1.0,2.0,4.1,5.1,10.2,20.4,40.8,81.6$, and $163.3 \mathrm{~g} \cdot \mathrm{L}^{-1}$ (weight of reconstituted mustard per liter of air) were evaluated for suppression of mycelial growth. Treatment effect was evaluated by measuring the radial growth of mycelia. Sclerotia were placed in culture tubes containing $18 \mathrm{~g}$ autoclaved soil and covered with an additional $5 \mathrm{~g}$ soil. AITC at concentrations of $0,4.0,16.0,64.0,256.0,1024.0$, or $4096.0 \mu \mathrm{mol} \cdot \mathrm{L}^{-1}$ was injected into the tubes. Treated sclerotia were removed from tubes and plated on potato dextrose agar to determine viability. Mycelial growth was inhibited with IM treatments $(P<0.01)$. Inhibiting concentrations (IC) of IM for mycelial growth inhibition of $50 \%$ and $90 \%$ were 0.7 and 1.0 $\mathrm{g} \cdot \mathrm{L}^{-1}$, respectively, with death resulting with $>2 \mathrm{~g} \cdot \mathrm{L}^{-1}$. Inhibition attributable to AITC alone was lower than that achieved by IM producing equivalent amounts of AITC. Germination of sclerotia was negatively correlated with AITC concentration $(r$ $=0.96 ; P<0.01$ ). The $\mathrm{IC}_{50}$ and $\mathrm{IC}_{90}$ of $\mathrm{AITC}$ were 249.0 and $528.8 \mu \mathrm{mol} \cdot \mathrm{L}^{-1}$, respectively, at 42 hours. The lethal concentration for sclerotia was not reached; only suppression occurred at the highest treatment concentrations. Sclerotium rolfsii mycelia were sensitive to the IM volatiles and were suppressed at low concentrations. Sclerotia were more resistant than the mycelia and required higher concentrations of AITC to suppress germination.
\end{abstract}

By 2005, methyl bromide will be banned for agricultural use, in accordance with the U.S. Clean Air Act and the Montreal Protocol (U.S. Dept. Agr., 1999). As the predominant soil fumigant for broad-spectrum control of weeds, nematodes, and soilborne pathogens, the loss of methyl bromide will have a dramatic and immediate impact on agriculture. Although alternative chemical controls are available, none provide the broad-spectrum results achieved with methyl bromide. The need for alternative methods of controlling these pests and increased interest in reducing synthetic chemical inputs has prompted an increase in research on cultural and biological disease control. Glucosinolates (GSL), found in Brassica species, are of particular interest because their volatile degradation products have biocidal activity.

The genus Brassica L. contains $>37$ species, which include food crops such as turnip [B. campestris L. (Rapifera Group)], black mustard (B. nigra (L.) W.D.J. Koch), white mustard (B. hirta Moench), Chinese cabbage [B. rapa L. (Pekinensis Group)], and the diverse structural variants of $B$. oleracea $L$. including cabbage (Capita Group), broccoli (Botrytis Group) and cauliflower (Botrytis Group) (Ludford and Isenberg, 1994). This genus and all tested members of the Brassicaceae family have been reported to produce GSL.

Glucosinolates are organic anions containing B-D-thioglucose and sulfonated oxime moieties (Brown et al., 1994) derived from methionine, tryptophan, and phenylalanine (Underhill et al., 1973). When hydrolyzed by the enzyme myrosinase, GSL produce D-glucose, sulfate, isothiocyanates (volatile mustard oils), thiocyanates, and nitriles (Larsen, 1981; Poulton and Moller, 1993). Both GSL and myrosinase occur in cells throughout the plant, but are

Received for publication 11 April 2001. Accepted for publication 7 Sept. 2001 Mention of a trademark, proprietary product, or vendor does not constitute a guarantee or warranty of the product by the University of Tennessee and does not imply its approval to the exclusion of other products or vendors that also may be suitable. The cost of publishing this paper was defrayed in part by the payment of page charges. Under postal regulations, this paper therefore must be hereby marked advertisement solely to indicate this fact.

${ }^{1}$ Corresponding author. isolated from each other. They mix and react when cells are damaged (Chew, 1988).

The breakdown products of GSL are toxic to fungi (Charron and Sams, 1999; Mayton et al., 1996; Sarwar et al., 1998) bacteria (Delaquis and Mazza, 1995), nematodes (Mojtahedi et al., 1991, 1993), insects (Noble et al., 1999) and some weed seeds in laboratory experiments (Al-Khatib et al., 1997). The fungicidal properties of isothiocyanates (ITC) have been reported since 1937 (Walker et al., 1937). The chemical concentration necessary to demonstrate inhibition of a given fungus varies with the specific ITC. The type of ITC produced depends on the side chains of the glucosinolate from which it is derived. The concentration of ITC produced varies with environmental factors. Soil texture, temperature, microbial community, and $\mathrm{pH}$ can significantly affect the conversion of GSL to ITC (Price, 1999).

Sclerotium rolfsii has an extensive host range of more than 270 plant species in the United States alone and includes dicotyledons and monocotyledons (Farr et al., 1989). Many commercial crops including peanut (Arachis hypogaea L.), bean (Phaseolus L. sp.), sugarbeet [Beta vulgaris L. (Crassa Group)], sweet pepper (Capsicum frutescens L.) and tomato (Lycopersicon esculentum Mill.) are affected (Singleton et al., 1992). Some members of the Brassicaceae are reported to host $S$. rolfsii (Jyoti et al., 1994). The fungus causes southern blight (seedling damping-off, blight, and stem rot) throughout the tropics, subtropics, and in areas of the southern and southeastern United States. Sclerotium rolfsii produces survival structures, called sclerotia that are typically brown to tan in color and measure 0.5 to $2.0 \mathrm{~mm}$ in diameter. A sclerotium is comprised of a melanized outer layer, a middle cortex, and an innermost medulla of loosely arranged filamentous hyphae (Chet et al., 1969). Germinating sclerotia initiate new infections under conditions suitable for fungal growth.

In high value crops, southern blight incidence can be reduced with preplant applications of methyl bromide, chloropicrin, or metham-sodium (Jenkins and Averre, 1986). The organochlorine fungicide pentachloronitrobenzene is suggested for control of southern blight in heavily infested tomato fields (University of Tennessee 
Agricultural Extension Service, 2000). Several newer fungicides, tebuconazole $[\alpha-[2-(4-c h l o r o p h e n y l) e t h y l]-\alpha-(1-1-d i m e t h y l e t h y l)-1 H-$ 1,2,4-triazole-1-ethanol], flutolanil [N-[3-(1-methylethoxy)phenyl]-2(trifluoromethyl) benzamide], and fluazinam [3-chloro- $N$-(3-chloro5-trifluoromethyl-2-pyridyl)-trifluoro-2,6-dinitro- $p$-toluidine], are also effective for control of southern blight (Hagan and Olive, 1999). However, these fungicides do not control nonfungal pests and all are relatively expensive. There is also growing consumer concern over the use of chemicals in fruit and vegetable production, which may make the future of all of these chemicals questionable. These factors have stimulated interest in biologically based pest management such as biofumigation using Brassica sp.

The objective of this research was to determine, in vitro, the toxicity of the Indian mustard (Brassica juncea) volatiles and allyl isothiocyanates (AITC) to $S$. rolfsii. Specifically, we examined 1) inhibition of mycelial growth by Indian mustard, 2) AITC released by Indian mustard, and 3) suppression of sclerotia germination by AITC.

\section{Materials and Methods}

Plant material and general Procedures. During Fall 1998, Indian mustard (PI 458934; U.S. Dept. Agr./Agr. Res. Serv., Ames, Iowa) was grown at the University of Tennessee, Plant Science Unit of the Knoxville Experiment Station, Knoxville, Tenn. Whole Indian mustard plants were harvested at anthesis. Plants were lyophilized (Labconco, Kansas City, Mo.) and ground to pass a 20mesh (0.84-mm) screen. Plant tissue was homogenized to reduce sampling error associated with the small amounts of residues needed for the experiments. Freeze-dried Indian mustard (FDM) was stored over silica desiccant until used. The volatiles of interest produced from FDM are similar to those produced by fresh Indian mustard (Price, 1999).

An isolate of $S$. rolfsii was collected from tomato (Lycopersicon esculentum L.) grown in Fall 1999 at the Knoxville (Tenn.) Experiment Station. The isolate was cultured on potato dextrose agar (PDA) and was maintained in the laboratory. Sclerotia used in this experiment were grown on PDA. Plugs from an actively growing culture were placed on fresh PDA petri plates and placed in an incubator (Kelvinator Commercial Products, Manitowoc, Wis.) at $30^{\circ} \mathrm{C}$. Plates were not sealed and sclerotial formation on PDA was triggered by desiccation at $20 \%$ relative humidity $(\mathrm{RH})$. Formation occurred within 2 weeks and sclerotia were air dried 2 weeks at $30 \%$ RH. Sclerotia formed in this manner appeared more similar to soil formed sclerotia in size, texture, color, and germination rate than sclerotia formed on sealed plates (unpublished data).

INHIBITION OF MYCELIAL GROWTH BY INDIAN MUSTARD. Freezedried Indian mustard and water were mixed in a 490-mL glass jar and treatments of $0,0.1,0.2,0.6,1.0,2.0,4.1,5.1,10.2,20.4,40.8$, 81.6, and $163.3 \mathrm{~g}$ reconstituted FDM per liter of enclosed atmosphere were established. Deionized water was added to reconstitute FDM to its fresh weight $(9.160 \pm 0.001 \mathrm{~g}$ water per $1.000 \pm 0.001 \mathrm{~g}$ FDM). Plugs (4.6 mm diameter) were cut from margins of an actively growing $S$. rolfsii culture and placed in the center of fresh PDA plates $(100 \times 15 \mathrm{~mm})$. Plates with hyphal plugs were inverted, agar side down, over the mouth of the jars and sealed with wax film. This process was repeated for each treatment.

Jars were incubated at $30^{\circ} \mathrm{C}$ for $42 \mathrm{~h}$. Jars were removed and radial growth of the colony on agar was measured. When mycelial growth from the plug was nonsymmetrical, four radii were taken and averaged. Percentage inhibition of growth was calculated from the difference between growth of treated plugs and control. Plugs exhibiting zero (0) growth following treatment were transferred to fresh PDA and incubated at $30^{\circ} \mathrm{C}$ for an additional $42 \mathrm{~h}$ to determine if suppression or death had occurred.

To determine the amount of inhibition that was attributable to the AITC released by the remoistened FDM, hyphal plugs were fumigated with AITC standard (diluted in ethanol) at concentrations of $0.3,0.8,1.7$, 2.9 , and $6.0 \mu \mathrm{mol} \cdot \mathrm{L}^{-1}$ enclosed atmosphere. The dilutions were applied to filter paper (Whatman No. 2) in the bottom of the 490-mL jars. Plates with hyphal plugs were inverted over the mouth of each jar. The rest of the procedure was the same as that used with the FDM.

A completely randomized design was used for an experiment with four replications of the Indian mustard treatments and three replications of the AITC dilutions. To examine the dosage effect, a nonlinear regression of the percentage inhibition was performed. From the sigmoid equation $\mathrm{Y}=\mathrm{a} /\left(1+e^{-(\mathrm{X}-\mathrm{B} / \mathrm{C})}\right)$, the concentrations of FDM and AITC to produce $50 \%$ and $90 \%$ inhibition $\left(\mathrm{IC}_{50}\right.$ and $\mathrm{IC}_{90}$ ) were calculated (SigmaPlot, 2000).

DETERMinAtion OF AITC RELEASED By INDIAN MUSTARD. Freezedried Indian mustard and water were mixed in 490-mL glass jars, which were then sealed with Teflon lids with septa. Treatments of $0,0.05,0.10,0.30,0.50,1.0,2.0,2.5$, and $5.0 \mathrm{~g}$ of reconstituted FDM were selected for analysis. AITC dilutions (in ethanol) for the standard curve were made from AITC standard (Sigma-Aldrich Corp, St. Louis). Jars were incubated at $30^{\circ} \mathrm{C}$ for $15 \mathrm{~min}$ before sampling for $1 \mathrm{~min}$ with a $100 \mu \mathrm{m}$ polydimethylsiloxane Solid Phase MicroExtraction (SPME) fiber(Supelco, St. Louis). The fiber was placed in the injection port of a Hewlett Packard 5890 gas chromatograph (GC) equipped with a Hewlett Packard 5972 mass selective (MS) detector to desorb for $1 \mathrm{~min}$. The column was an Alltech EC Wax $30 \times 0.25 \times 0.25$ (Alltech Associates, Inc., Deerfield, Ill.). The inlet and outlet temperatures were 200 and 280 ${ }^{\circ} \mathrm{C}$, respectively. The oven parameters were programmed at $60^{\circ} \mathrm{C}$ for $1 \mathrm{~min}$, and then increased by $5^{\circ} \mathrm{C}$ per min to a maximum of 150 ${ }^{\circ} \mathrm{C}$. Detector response was quantified based on the equation for the AITC standard curve.

This experiment used a completely randomized design with four replications. Linear regression was used to produce the equations for quantifying AITC production and for describing the relationship between AITC release and FDM (Sigma Plot, 2000).

SuPPRESSION OF SClERotia GERMINATION BY AITC. Sclerotia were grown as described previously, collected, air-dried, and screened to uniformity ( $\geq 1$ and $<2 \mathrm{~mm}$ diameter). Five sclerotia were selected and placed on a $2-\mathrm{cm}$ square of $0.2-\mathrm{mm}$ polyester mesh. The mesh was then tied up around the five sclerotia. For each treatment, a

Table 1. Radial growth \pm SD and inhibition of Sclerotium rolfsii mycelia at $42 \mathrm{~h}$ after treatment with reconstituted Indian mustard residues.

\begin{tabular}{lcc}
\hline $\begin{array}{l}\text { Indian mustard } \\
(\mathrm{g} \mathrm{FW} / \mathrm{L})\end{array}$ & $\begin{array}{c}\text { Radial growth of mycelia } \\
\mathrm{z}\end{array}$ & $\begin{array}{c}\text { Inhibition }^{\mathrm{z}} \\
(\%)\end{array}$ \\
\hline 0.00 & $21.4 \pm 2.5$ & 0.0 \\
0.10 & $18.5 \pm 2.8$ & 12.4 \\
0.20 & $17.0 \pm 2.4$ & 16.2 \\
0.61 & $14.5 \pm 6.0$ & 29.6 \\
1.02 & $1.4 \pm 2.5$ & 77.9 \\
$>2.00$ & $0.0 \pm 0.0$ & 100.0 \\
Nonlinear regression $^{\mathrm{y}}$ & $* *$ & $* *$ \\
& &
\end{tabular}

${ }^{\mathrm{z}}$ Mean of four replications.

${ }^{y}$ Analysis of dosage effect was performed using SigmaPlot nonlinear regression model $\left(\mathrm{Y}=\mathrm{a} /\left(1+e^{-(\mathrm{X}-\mathrm{B} / \mathrm{C})}\right)\right.$. Dosages in excess of that needed to induce $100 \%$ inhibition were eliminated from the analysis.

${ }^{* * *}$ Significant at $P \leq 0.01$. 


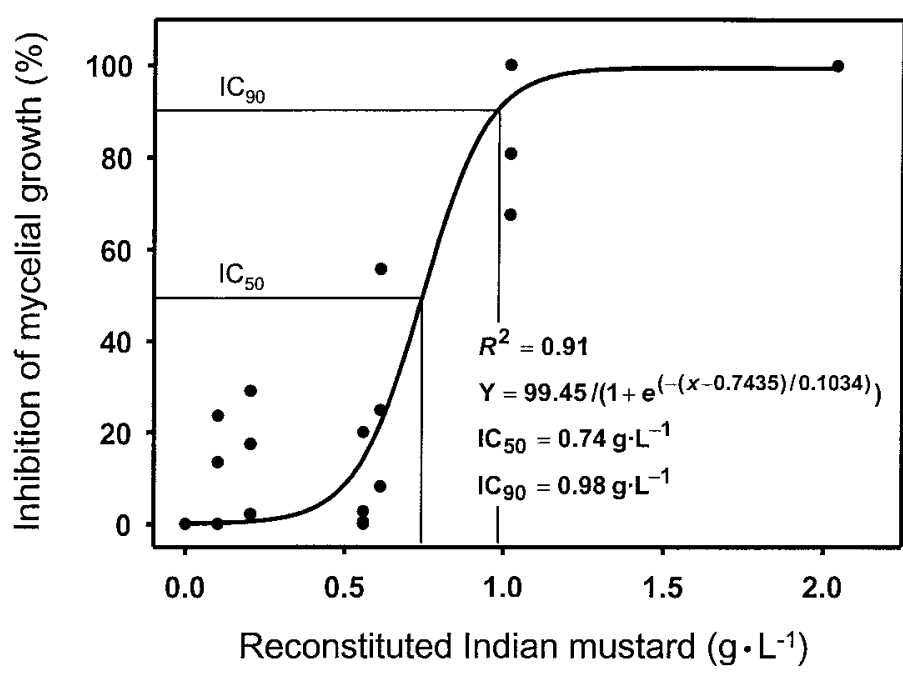

Fig. 1. Inhibition of mycelial growth of Sclerotium rolfsii with treatments of reconstituted Indian mustard (Brassica juncea) residues. The $\mathrm{IC}_{50}$ and $\mathrm{IC}_{90}$ (inhibiting concentration at $50 \%$ and $90 \%$ ) were calculated from the equation produced by the nonlinear regression.

culture tube was packed with $15.60 \pm 0.05 \mathrm{~g}$ of oven-dried clay loam soil (fine, kaolinitic, thermic, Typic Paleudult). The soil was brought to $\approx 60 \%$ field capacity with the addition of $2.4 \mathrm{~g}$ deionized water. Additional soil $(\approx 5 \mathrm{~g}$ per tube) was weighed into a beaker and moistened similarly. The tubes, beaker, and soil therein were autoclaved to eliminate potential effects of antagonistic organisms. Following autoclaving, sterile deionized water was added to the tubes and beaker to return them to their preautoclave weight $(\approx 60 \%$ field capacity).

A mesh bag containing the sclerotia was placed on top of the soil in each tube and covered with $5 \mathrm{~g}$ of additional soil. Tubes were capped with septa. The treatments of AITC per headspace volume included $0.0,4.0,16.0,64.0,256.0,1024.0$, and $4096.0 \mu \mathrm{mol} \cdot \mathrm{L}^{-1}$. The AITC treatment was injected through the septa and into the tube. Tubes were incubated at $30^{\circ} \mathrm{C}$ for $24 \mathrm{~h}$ and then checked for AITC concentration using GC-MS (Price, 1999). If no AITC was detected, bags were removed from tubes and surface-sterilized with $0.5 \%$ sodium hypochlorite followed by a deionized water rinse. Sclerotia were removed and placed on PDA, an equal distance from each other and incubated at $30^{\circ} \mathrm{C}$ for $42 \mathrm{~h}$. Radial growth of mycelia from sclerotia was measured. Sclerotia exhibiting zero growth were

Table 2. Radial growth \pm SD and inhibition of Sclerotium rolfsii mycelia at $42 \mathrm{~h}$ after treatment with known concentrations of allyl isothiocyanates (AITC).

\begin{tabular}{lcc}
\hline \hline $\begin{array}{l}\text { AITC } \\
\left(\mu \mathrm{mol} \cdot \mathrm{L}^{-1}\right)\end{array}$ & $\begin{array}{c}\text { Radial growth of mycelia } \\
(\mathrm{mm})\end{array}$ & $\begin{array}{c}\text { Inhibition }^{\mathrm{z}} \\
(\%)\end{array}$ \\
\hline 0.0 & $27.2 \pm 1.3$ & 0.0 \\
0.3 & $21.2 \pm 1.4$ & 5.7 \\
0.8 & $16.3 \pm 1.4$ & 39.7 \\
1.9 & $11.8 \pm 0.3$ & 56.4 \\
2.9 & $6.7 \pm 2.9$ & 70.0 \\
6.0 & $0.0 \pm 0.0$ & 100.0 \\
Nonlinear regression $^{\mathrm{y}}$ & $* *$ & $* *$
\end{tabular}

\footnotetext{
${ }^{\mathrm{z}}$ Mean of three replications.

yAnalysis of dosage effect was performed using SigmaPlot nonlinear regression model $\left(\mathrm{Y}=\mathrm{a} /\left(1+e^{-(\mathrm{X}-\mathrm{B} / \mathrm{C})}\right)\right.$. Dosages in excess of that needed to induce $100 \%$ inhibition were eliminated from the analysis.

*** Significant at $P \leq 0.01$.
}

monitored for $7 \mathrm{~d}$ to determine if suppression or death had occurred.

A completely randomized design with four replications and five samples per experimental unit was used. To examine the dosage effect, a nonlinear regression of percentage inhibition was performed. From the sigmoid equation $\mathrm{Y}=\mathrm{a} /\left(1+e^{-(\mathrm{X}-\mathrm{B} / \mathrm{C})}\right)$, the concentrations to produce $50 \%$ and $90 \%$ inhibition $\left(\mathrm{IC}_{50}\right.$ and $\mathrm{IC}_{90}$ ) were calculated (SigmaPlot, 2000).

\section{Results}

INHIBITION OF MYCELIAL GROWTH BY INDIAN MUSTARD. Mycelia of $S$. rolfsii were sensitive to volatiles produced by FDM. Treatments in excess of $2.0 \mathrm{~g} \cdot \mathrm{L}^{-1}$ Indian mustard resulted in death of $S$. rolfsii (Table 1). The $\mathrm{IC}_{50}$ and $\mathrm{IC}_{90}$ values 0.74 and $0.98 \mathrm{~g} \cdot \mathrm{L}^{-1}$ of reconstituted FDM, respectively were calculated from the equation $\mathrm{Y}=$ $99.45 /\left(1+e^{(-(\mathrm{X}-0.7435) / 0.1034)}\right)\left(R^{2}=0.91 ; \mathrm{SE} \pm 13.82\right)($ Fig. 1$)$.

AITC inhibition of mycelial growth was also investigated. Sclerotium rolfsii was sensitive to AITC (Table 2). The nonlinear regression of the inhibition of radial growth $\left(R^{2}=0.94\right.$; SE \pm 9.63$)$ produced the equation $\mathrm{Y}=98.59 /\left(1+e^{(-(\mathrm{X}-1.6890) / 0.8593)}\right)$, from which an $\mathrm{IC}_{50}$ and $\mathrm{IC}_{90}$ of AITC at 1.6 and $4.5 \mu \mathrm{mol} \cdot \mathrm{L}^{-1}$, respectively, were calculated (Fig. 2).

Determination of AITC Released by Indian mustard. Headspace sampling and GC-MS analysis was used to determine the concentration of AITC released from Indian mustard. A highly significant linear relationship existed $\left(R^{2}=0.99 ; \mathrm{SE} \pm 0.11\right)$. The equation describing this relationship was: $\operatorname{AITC}\left(\mu \mathrm{mol} \cdot \mathrm{L}^{-1}\right)=0.41$ $\times$ Indian mustard $[\mathrm{g}$ fresh weight $(\mathrm{FW}) / \mathrm{L}]+0.59$.

Indian mustard treatments were more effective than equivalent AITC treatments (Fig. 3). AITC concentrations eliciting predicted levels of inhibition were translated to Indian mustard concentrations, based on the equations describing the relationships of AITC to mycelial inhibition and Indian mustard to AITC release. The second curve was constructed from this information to represent the inhibition of mycelial growth attributable to the AITC released by the Indian mustard. The $\mathrm{IC}_{50}$ and $\mathrm{IC}_{90}$ for the inhibition attributable to only the AITC were calculated at 2.7 and $7.6 \mathrm{~g} \mathrm{FW/L}$, respectively.

SuPPRESSION OF SCLEROTIA GERMINATION BY AITC. The sclerotia of $S$. rolfsii were resistant to treatment with AITC. None of the

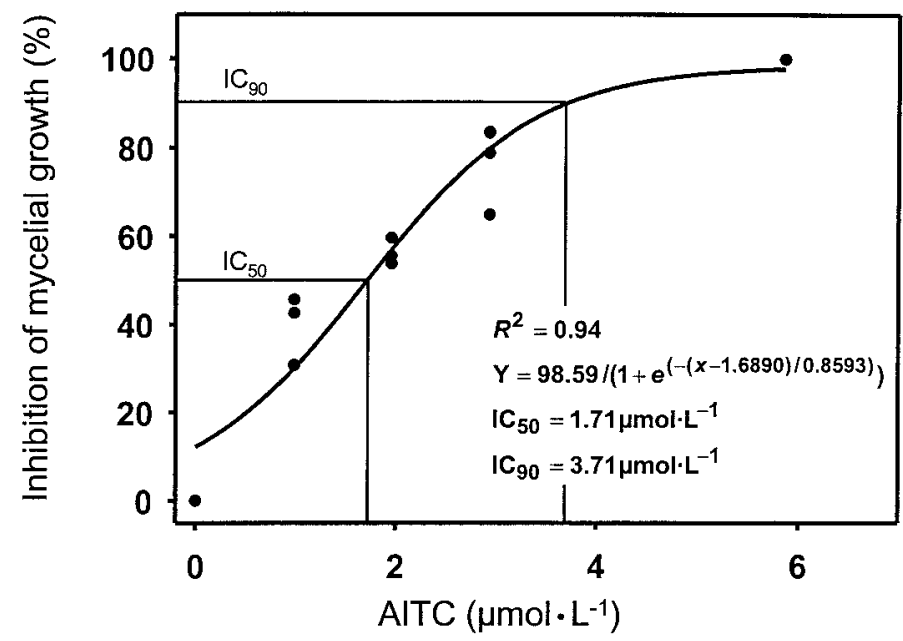

Fig. 2. Inhibition of mycelial growth of Sclerotium rolfsii by known concentrations of allyl isothiocyanate (in $\mu \mathrm{mol} \cdot \mathrm{L}^{-1}$ ). The $\mathrm{IC}_{50}$ and $\mathrm{IC}_{90}$ (inhibiting concentration at $50 \%$ and $90 \%$ ) were calculated from the equation produced by the nonlinear regression. 


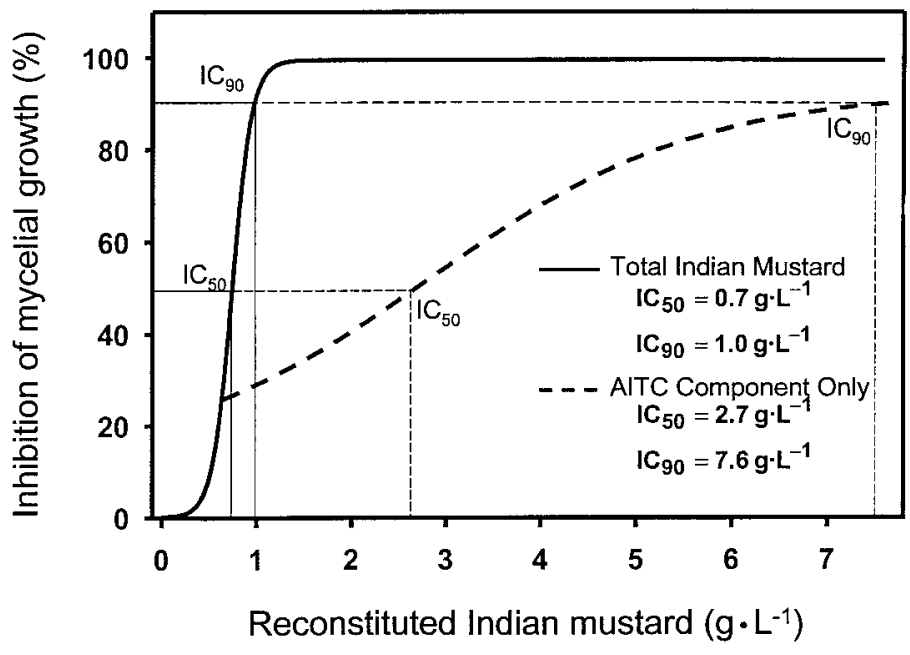

Fig. 3. Relationship between Indian mustard and inhibition of Sclerotium rolfsii mycelial growth (solid curve) and the projected amount of Indian mustard required to achieve the same inhibition, if AITC was the only factor involved in the inhibition (dashed curve). The $\mathrm{IC}_{50}$ and $\mathrm{IC}_{90}$ (concentration resulting in $50 \%$ and $90 \%$ inhibition, respectively) were calculated for each equation for comparison.

treatment levels was sufficient to kill sclerotia; however, suppression was achieved at high concentrations (Table 3). The equation, $\mathrm{Y}$ $=95.54 /\left(1+e^{(-(\mathrm{X}-239.29) / 103.81)}\right)$, from the nonlinear regression of inhibition $\left(R^{2}=0.96\right.$; $\left.\mathrm{SE} \pm 9.54\right)$ was used to calculate the $\mathrm{IC}_{50}$ and $\mathrm{IC}_{90}$ of 249.0 and $528.8 \mu \mathrm{mol} \cdot \mathrm{L}^{-1}$ AITC, respectively (Fig. 4). Suppressed sclerotia germinated 6 to $8 \mathrm{~d}$ after transfer to PDA.

\section{Discussion}

Volatiles released from $2.0 \mathrm{~g}$ Indian mustard into a headspace volume of $1 \mathrm{~L}$ (equaling AITC at $1.45 \mu \mathrm{mol} \cdot \mathrm{L}^{-1}$ ) proved effective for lethal inhibition of $S$. rolfsii mycelial growth. Based on average soil porosity and Indian mustard production of leaf biomass at $12 \mathrm{t} \cdot \mathrm{ha}^{-1}$ (Duke, 1984), the biomass needed for fumigation (approximately $1.68 \mathrm{t} \cdot \mathrm{ha}^{-1}$ ) is achievable in field plantings. This is supported by the work of Chan and Close (1987) and Subbarao and Hubbard (1996). Their research with Brassica crop residues has demonstrated effective control of other pathogens in field settings.

Table 3. Radial growth \pm SD and inhibition of Sclerotium rolfsii mycelia from germinating sclerotia at $42 \mathrm{~h}$ after treatment with different concentrations of allyl isothiocyanates (AITC).

\begin{tabular}{lcc}
\hline \hline $\begin{array}{l}\text { AITC } \\
\left(\mu \mathrm{mol} \cdot \mathrm{L}^{-1}\right)\end{array}$ & $\begin{array}{c}\text { Radical growth of mycelia } \\
(\mathrm{mm})\end{array}$ & $\begin{array}{c}\text { Inhibition }^{2} \\
(\%)\end{array}$ \\
\hline 0.0 & $7.2 \pm 2.0$ & --- \\
4.0 & $7.0 \pm 2.7$ & 6.4 \\
16.0 & $6.4 \pm 2.6$ & 26.9 \\
64.0 & $7.5 \pm 1.7$ & 13.7 \\
256.0 & $4.2 \pm 3.8$ & 50.0 \\
1024.0 & $0.7 \pm 0.7$ & 91.5 \\
4096.0 & $0.0 \pm 0.0$ & 100.0 \\
Nonlinear regression $^{\mathrm{y}}$ & $* *$ & $* *$
\end{tabular}

$\overline{{ }^{\mathrm{z}} \text { Means represent an average of four replications with five samples per }}$ replication.

${ }^{y}$ Analysis of dosage effect was performed using SigmaPlot nonlinear regression model $\left(\mathrm{Y}=\mathrm{a} /\left(1+e^{-(\mathrm{X}-\mathrm{B} / \mathrm{C})}\right)\right.$. Dosages in excess of that needed to induce $100 \%$ inhibition were eliminated from the analysis.

${ }^{* * *}$ Significant at $\mathrm{P} \leq 0.01$
Other application methods have also proven effective. Kirkegaard et al. (1996) were successful in suppressing soilborne cereal pathogens with mustard seed meal. The high glucosinolate meal was applied with wheat (Triticum aestivum $\mathrm{L}$.) seeds and fertilizer using a grain drill.

The predicted concentrations of Indian mustard necessary for inhibition of $S$. rolfsii mycelial growth were four times the concentrations actually observed, if AITC alone was responsible for the inhibition. This suggests that other chemicals released by the Indian mustard also play a role in its toxicity. AITC and other compounds acting together could be providing greater inhibition than either compound individually.

Use of AITC directly as a general soil fumigant has been suggested (Minuto et al., 1999). A similar compound, methyl isothiocyanates (MITC), is released from the commercial fumigant metam-sodium. AITC inhibited mycelial growth of $S$. rolfsii at concentrations in excess of $4.5 \mu \mathrm{mol} \cdot \mathrm{L}^{-1}$. Inhibition of $S$. rolfsii sclerotial germination is more difficult to achieve with AITC than the inhibition of actively growing mycelia. At concentrations approaching 200 times those required to kill mycelia, sclerotia were only suppressed and recovered by day seven. MITC is sublethal at concentrations $<620 \mu \mathrm{mol} \cdot \mathrm{L}^{-1}$ soil airspace (based on $23 \mu \mathrm{g} \cdot \mathrm{g}^{-1}$ soil (Hoynes et al., 1999) assuming an average soil bulk density of 1.5 $\mathrm{g} \cdot \mathrm{cm}^{-3}$ ). A higher concentration may prove toxic; however, applying higher rates is questionable, since the cost of application may negate any benefit due to increased yields. Because soil was sterilized for this study, the potential for antagonistic attack by other fungi or bacteria did not exist. In a natural soil environment, the AITC treatments might have weakened the sclerotia, making them more vulnerable to attack by antagonist (Lifshitz et al., 1983). This aspect will require further investigation. In addition, if sclerotia can be triggered to germinatebefore treatment, lower concentrations of AITC/mustard could provide adequate inhibition of both the saprophytic and newly emerged mycelia of $S$. rolfsii. Although not currently equivalent in total disease control, biofumigation offers growers an alternative to methyl bromide.

Other alternative methods for disease control have been successful under limited conditions. Fallow solarization is reported to reduce sclerotial survival and limit disease due to $S$. rolfsii (Chellemi et al, 1997; Lewis and Fravel, 1996; Ristaino et al., 1996). The

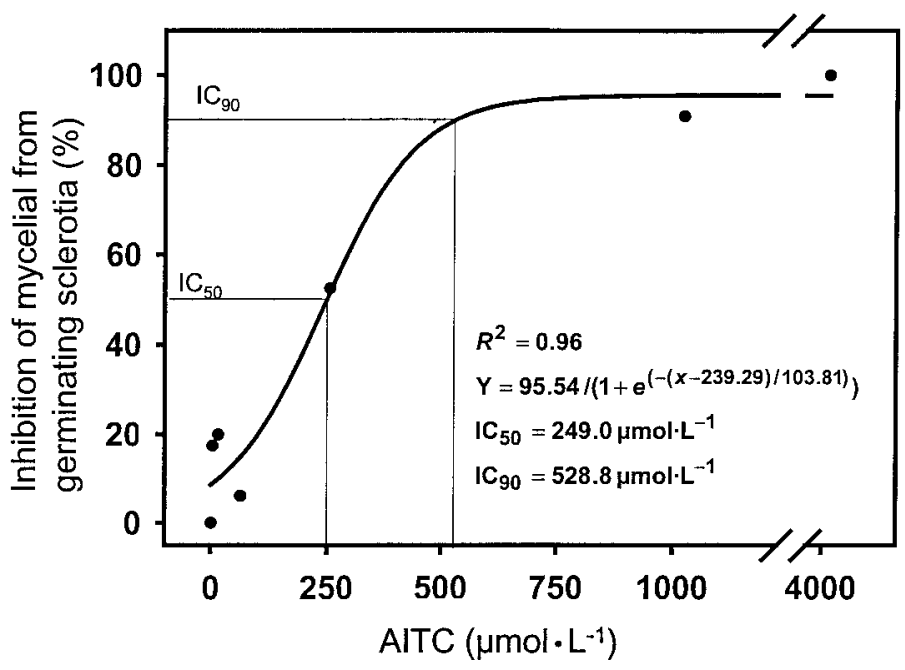

Fig. 4. Inhibition of mycelial growth from germinating sclerotia of Sclerotium rolfsii by known concentrations of allyl isothiocyanate (in $\left.\mu \mathrm{mol} \cdot \mathrm{L}^{-1}\right)$. The $\mathrm{IC}_{50}$ and $\mathrm{IC}_{90}$ (concentration resulting in 50\% and $90 \%$ inhibition, respectively) were calculated from the equation produced by the nonlinear regression. 
combination of solar heating and the introduction of antagonistic microbes, such as Trichoderma harzianum Rifai, resulted in less disease than either method alone (Lumsden and Papavizas, 1988; Ristaino et al., 1996). The efficacy of these methods is limited by climate, soil type, and pathogen isolate differences. If biofumigation is combined with other cultural practices, such as solarization, compost amendments and/or integrated use of pesticides, disease control may be further improved.

\section{Literature Cited}

Al-Khatib, K., C. Libby, and R. Boydstom. 1997. Weed suppression with Brassica green manure crops in green peas. Weed Sci. 45:439-445.

Brown, P.D., M. Morra, and V. Borek. 1994. Gas chromatography of allelochemicals produced during glucosinolate degradation in soil. J. Agr. Food Chem. 42:2029-2034.

Chan, M. and R. Close. 1987. Aphanomyces root rot of peas: Control by the use of cruciferous amendments. N.Z. J. Agr. Res. 30:225-233.

Charron, C.S. and C.E. Sams. 1999. Inhibition of Pythium ultimum and Rhizoctonia solani by shredded leaves of Brassica species. J. Amer. Soc. Hort. Sci. 124:462-467.

Chellemi, D.O., S. Olson, D. Mitchell, I. Secker, and R. McSorley. 1997. Adaptation of soil solarization to the integrated management of soilborne pests of tomato under humid conditions. Phytopathology 87:250-258.

Chet, I., T. Henis, and N. Kislev. 1969. Ultrastructure of sclerotia and hyphae of Sclerotium rolfsii Sacc. J. Gen. Microbiol. 57:143-147.

Chew, F.S. 1988. Biological effects of glucosinolates, p. 155-181. In: H.G. Cutler (ed.). Biologically active products: Potential use in agriculture. Amer. Chem. Soc., Wash., D.C.

Delaquis, P. J. and G. Mazza. 1995. Antimicrobial properties of isothiocyanates in food preservation. Food Technol. 49:73-84.

Duke, J. 1984. Handbook of energy crops.

www.hort.purdue.edu/newcrop/duke_energy/Brassica_juncea. html\#Harvesting.

Farr, D.F., G.F. Bills, G.P. Chamuris, and A.Y. Rossman. 1989. Fungi on plants and plant products in the United States. Amer. Phytopathol. Soc., St. Paul, Minn.

Hagan, A. and J. Olive, 1999. Assessment of new fungicides for the control of southern blight of aucuba. J. Environ. Hort. 17:73-75.

Hoynes, C.D., J.A. Lewis, R.D. Lumsden, and G.A. Bean. 1999. Biological control agents in combination with fertilization or fumigation to reduce sclerotial viability of Sclerotium rolfsii and disease of snap beans in the greenhouse. J. Phytopathol. 147:175-182.

Jenkins, S.F. and C. Averre. 1986. Problems and progress in integrated control of southern blight of vegetables. Plant Dis. 70:614-618.

Jyoti, M., A.K. Pandey, R.C. Rajak, and S.K. Hasija. 1994. Microbial management of parthenium-I host specificity of Sclerotium rolfsii Sacc. Natl. Acad. Sci. Lett. 17:169-173.

Kirkegaard, J., P. Wong, J. Desmarchelier, and M. Sarwar. 1996. Suppression of soil-borne cereal pathogens and inhibition of wheat germination by mustard seed meal. Proc. Austral. Agron. Conf. 8:353-356.

Larsen, P.O. 1981. Glucosinolates, p. 501-525. In: E.E. Conn (ed.). The biochemistry of plants. Academic Press, Toronto.

Lewis, J.A. and D.R. Fravel. 1996. Influence of pyrax/biomass of biocontrol fungi on snap bean damping-off caused by Sclerotium rolfsii in the field and on germination of sclerotia. Plant Dis. 80:655-659.

Lifshitz, R., M. Tabachnik, J. Katan, and I. Chet. 1983. The effect of sublethal heating on sclerotia of Sclerotium rolfsii. Can. J. Microbiol. 29:1607-1610.

Ludford, P.M. and F.M.R Isenberg. 1994. Brassica crops, p. 497-522. In: J.Weichmann(ed.). Postharvest physiology of vegetables. MarcelDekker, New York.

Lumsden, R. and G. Papavizas. 1988. Biological control of soilborne plant pathogens. Amer. J. Alternative Agr. 3:98-101.

Mayton, H. S., C. Olivier, S.F. Vaughn, and R. Loria. 1996. Correlation of fungicidal activity of Brassica species with allyl isothiocyanate production in macerated leaf tissue. Phytopathology 86:267-271.

Minuto, A., G. Gilardi, A. Pome, and M.L. Gullino. 1999. Soil fumigation with allylisothiocyanate: Preliminary results in Italy. Proc. Annu. Intl. Res. Conf. Methyl Bromide Alternatives Emissions Reductions 40-1.

Mojtahedi, H., G. Santo, and A. Hang. 1993. Managing Meloidogyne chitwoodi on potato with rapeseed as green manure. Plant Dis. 77:42-46.

Mojtahedi, H., G. Santo, A. Hang, and J. Wilson. 1991. Suppression of rootknot nematode populations with selected rapeseed cultivars as green manure. J. Nematol. 23:2-174.

Noble, R., S. Charron, and C. Sams. 1999. Toxicity of Indian mustard and allyl insothiocyanate to masked chaffer beetle larvae. Proc. Annu. Intl. Res. Conf. Methyl Bromide Alternatives Emissions Reductions 92-1.

Poulton, J.E. and B. Moller. 1993. Glucosinolates, p. 209-237. In: P.J. Lea (ed.). Methods in plant biochemistry. vol. 9. Academic Press, Toronto.

Price, A. 1999. Quantification of volatile compounds produced during simulated biofumigation utilizing Indian mustard degrading in soil under different environmental conditions. MS thesis, Univ. Tenn., Knoxville.

Ristaino, J.B., K.B. Perry, and R.D. Lumsden. 1996. Soil solarization and Gliocladium virens reduce the incidence of southern blight (Sclerotium rolfsii) in bell pepper in the field. Biocontrol Sci. Technol. 6:583-593.

Sarwar, M., J. Kirkegaard, P. Wong, and J. Desmarchelier. 1998. Biofumigation potential of Brassicas. III. In vitrotoxicity of isothiocyanates to soil-borne fungal pathogens. Plant Soil 201:103-112.

SigmaPlot. 2000. SigmaPlot 2000 for windows version 6.0. SPSS Sci., Inc., Chicago.

Singleton, L.L., J. Mihail, and C. Rush (eds.). 1992. Methods for research on soilborne phytopathogenic fungi. APS Press, St. Paul, Minn.

Subbarao, K. and J. Hubbard. 1996. Interactive effects of broccoli residue and temperature on Verticillium dahliae microsclerotia in soil and on wilt in cauliflower. Phytopathology 86:1303-1310.

Underhill, E.W., L.R. Wetter, and M.D. Chisholm. 1973. Biosynthesis of glucosinolates. Biochem. Soc. Symp. 38:303-326.

U.S. Department of Agriculture. 1999. Administration extends deadline on MeBr ban to 2005. Methyl Bromide Alternatives 5:1.

University of Tennessee Agricultural Extension Service. 2000. Commercial vegetable disease, insect and weed control. Univ. Tenn. Agr. Ext. Serv, Knoxville. PB1282.

Walker, J.C., S. Morell, and H.H. Foster. 1937. Toxicity of mustard oils and related sulfer compounds to certain fungi. Amer. J. Bot. 24:536-541. 